\title{
Bivariate Analysis to Determine the Relationship of Behavior, Attitude, and Knowledge of Mother as Well as Information Exposure to the Occurrence of Pneumonia in Toddlers
}

\author{
$1^{\text {st }}$ Jumiati \\ Midwifery Department \\ Politeknik Aisyiyah Banten \\ Serang, Indonesia \\ jumiati.isro3@gmail.com
}

\author{
$2^{\text {nd }}$ Qonita \\ Midwifery Department \\ Politeknik Aisyiyah Banten \\ Serang, Indonesia
}

\begin{abstract}
Pneumonia is the leading cause of child mortality in the world. This disease accounts for $16 \%$ of all deaths of children under 5 years of age, which causes death in 920,136 toddlers, or more than 2,500 per day, or an estimated 2 toddlers die every minute in 2015. This study aims to determine the relationship between the incidence of pneumonia in infants in Cilegon city caused by behavior, attitudes, knowledge of mothers and information exposure. The population and sample in this study were mothers who had toddlers scattered in 8 Puskesmas in Cilegon city as many as 366 respondents. The method used is quantitative method with design cross-sectional. Data collection was carried out by surveying the researcher conducting direct interviews with respondents using a questionnaire. The results of the study obtained the following data; Toddlers who have pneumonia are 97 Toddlers or $26.5 \%$, almost all 94.5\% Mothers have good knowledge about Pneumonia, $46.7 \%$ of mothers have sufficient behavior and $49.5 \%$ of mothers have sufficient attitude and more than half of the 70.2\% of mothers have not been exposed to information about pneumonia. Bivariate results found that attitudes and information exposure have a significant relationship to the incidence of pneumonia, whereas behavior and knowledge do not have a significant relationship to the incidence of pneumonia in toddlers in Cilegon city. From the results of this study, it is expected that the Health Office of in Cilegon city can improve socialization and counseling about pneumonia through collaboration with relevant agencies so that it can improve the degree of public health.
\end{abstract}

Keywords-Behavior, Attitude, Knowledge, Pneumonia

\section{INTRODUCTION}

Pneumonia is the single largest infectious cause of death in children worldwide yet it can be prevented with simple interventions, and treated with low-cost, low-tech medication and care. It accounts for around $16 \%$ of all deaths of children under five years. It affects children and families everywhere, but is most prevalent in South Asia and sub-Saharan Africa. Children can be protected from pneumonia. WHO is working to increase access to preventive care and effective treatments [1]. Pneumonia is an acute infection of the lung tissue (alveoli) which can be caused by various microorganisms such as viruses, fungi, and bacteria. Symptoms of pneumonia are chills, fever, headache, coughing, phlegm, and shortness of breath. Pneumonia is the leading cause of child mortality in the world. This disease accounts for $16 \%$ of all deaths of children under 5 years of age, which causes death in 920,136 toddlers, or more than 2,500 per day, or an estimated 2 toddlers die every minute in 2015. Several cases of Pneumonia in Toddlers in Indonesia in 2017 namely as many as 447,431 cases $(46.34 \%)$, whereas in Banten Province alone there were 30,402 cases $(62.35 \%)$ and the number of under-five deaths due to pneumonia in Banten was 31 cases [2].

Cases of Pneumonia in toddlers in Cilegon City in 2017 there was a significant decrease from 797 Toddlers (2016) to 660 Toddlers (2017) consisting of 381 Boys and 279 Girls [3]. Pneumonia is the single largest cause of death in children globally in the World, namely $15 \%$ of more than 6 million deaths in children aged 5 years in 2013. The burden of death from pneumonia needs to be significantly reduced if the global child survival target is met [4]. According to the concept of Lawrence Green's behavior, one that influences one's health is one's knowledge and attitude. This level of knowledge will later shape one's attitude toward something. One's attitude will influence health behavior, one's positive attitude will produce positive health behavior as well [5].

Pneumonia is a public health problem in Banten Province, especially in Toddlers. According to a source from the Directorate General of P2P of the Republic of Indonesia Ministry of Health in 2016, the number of pneumonia cases in toddlers was $59.41 \% / 24.908$ underfives of the target number of pneumonia cases found in toddlers as many as 41,927 people. The incidence of pneumonia in Cilegon city is in the third-highest ranking in Banten Province after Lebak Regency and Tangerang City. The incidence of pneumonia in toddlers in Cilegon city in 2016 was found to be 4,310 (10\%) of the total number of toddlers in existence, namely 43,103 people, while the pneumonia cases that were handled were 797 (18.5\%) of pneumonia cases found in toddlers [3].

The main causes of pneumonia were contacted with someone with cough and severe pneumonia, exposure to household air pollution, malnutrition and 
feeding practices, especially early introduction of solid food for infants. Strong evidence was found in the results of his research, namely the relationship between sleeping together with someone with cough and severe pneumonia and non-severe pneumonia with $18 \%$ of severe cases estimated to be caused by risk factors. Malnutrition has strong evidence for the occurrence of severe pneumonia [4]. A relationship between the level of knowledge, attitudes, and behavior of parents with the level of pneumonia recurrence in Toddlers [6]. The factors of parent behavior or lifestyle practiced at home also determine the health of the child, such as the extent to which exposure to cooking smoke is based on the type of fuel used for cooking, household members who smoke, and there is a separate kitchen. Psychologically, maternal stress indirectly affects pneumonia, stress on mothers affects breastfeeding and the pattern of care for children under five which influences the nutritional status of children [7], [8]. Environmental factors such as dwellings with dense occupants, spatial planing, exposure to cigarette smoke or indoor air pollution play a role in the risk of pneumonia. The physical environment of a house that does not meet health requirements and fuel use behavior can increase the risk of various diseases, one of which is pneumonia [9], [10].

Attitude is a reaction or response that is still closed from someone to a stimulus or object. According to Newcomb, one of the social-psychological experts stated that the attitude was the readiness or availability to act and not the implementation of certain motives. Attitude is not yet an action or activity, but it is still a predisposition to the action of behavior. A person's attitude will affect health behavior, a positive attitude someone will produce positive health behaviors as well. Health knowledge will affect behavior as a result of the medium-term (intermediate impact) of health education. Furthermore, health behavior will influence the increasing public health indicators as the outcome of health education [5]. Mothers of toddlers with low knowledge are likely to have toddlers experiencing pneumonia by 0.4 times compared to mothers of toddlers who are highly knowledgeable [11].

The result of the study showed that there was a significant effect of maternal education on pneumonia in children under five. Children with high maternal education had lower risk of pneumonia by 1.41 times. This was in line with a study by [12] which stated that there was an effect of maternal education on pneumonia. The status of maternal education was related to gaps in prevention behavior and utilization of medical services. Parents with low educational level was a predispose to poor medical services and low pneumonia prevention behavior [13]. In addition, maternal education would determine the quality of care, social, and environmental factors given to the child. Mothers who were highly educated would determine the welfare of infants and children which related to their health and care [13]

\section{METHOD}

The approach used in this research is to use a quantitative approach with a cross-sectional approach where independent and dependent variable data are examined at the same time.The population and sample used in this study were mothers who had children under five in 8 Community Health Centers (PUSKESMAS) in Cilegon city, as many as 366 toddlers.

\section{RESULT AND DISCUSSION}

\section{A. Univariate Analysis}

\section{TABLE 1. GENESIS PNEUMOCYSTIS}

\begin{tabular}{|c|c|c|}
\hline Pneumonia & Total & Percentage \\
\hline Yes & 97 & 26.5 \\
\hline No & 269 & 73.5 \\
\hline Total & 366 & 100 \\
\hline
\end{tabular}

Based on table 1, shows that toddlers who experienced pneumonia were found $26.5 \%$ or 97366 Toddler on the total sample of respondents.

TABLE 2. MOTHER'S KNOWLEDGE OF PNEUMONIA

\begin{tabular}{|c|c|c|}
\hline Knowledge & Number of & Percentage \\
\hline Less & 7 & 1.9 \\
\hline Sufficient & 13 & 3.6 \\
\hline Good & 346 & 94.5 \\
\hline Total & 366 & 100 \\
\hline
\end{tabular}

Based on table 2, shows that most respondents have good knowledge about pneumonia that is $94.5 \%$ or 346 respondents.

\begin{tabular}{ccc}
\multicolumn{3}{c}{ TABLE 3. MATERNAL } \\
\hline Behavior & Number of & Percentages \\
\hline Less & 25 & 6.8 \\
Sufficient & 171 & 46.7 \\
Good & 170 & 46.4 \\
\hline Total & 366 & 100 \\
\hline
\end{tabular}

Based on table 3 , shows that $46.7 \%$ or 171 mothers have sufficient behavior.

TABLE 4. ATTITUDE MOTHER

\begin{tabular}{|c|c|c|}
\hline Attitude & Number of & Percentage \\
\hline Less & 65 & 17.8 \\
\hline Sufficient & 181 & 49.5 \\
\hline Good & 120 & 32.8 \\
\hline Total & 366 & 100 \\
\hline
\end{tabular}

Based on Table 4, show that $49.5 \%$ or 181 mothers have enough attitude. 
TABLE 5. EXPOSURES PNEUMONIAI NFORMATION ON

\begin{tabular}{|c|c|c|}
\hline $\begin{array}{c}\text { Exposures } \\
\text { Information }\end{array}$ & Number of & Percentage \\
\hline Yes & 109 & 29.8 \\
\hline No & 257 & 70.2 \\
\hline Total & 366 & 100 \\
\hline
\end{tabular}

Based on table 5, shows that more than half of mothers are not exposed to information about pneumonia that is $70.2 \%$ or 257 respondents.

\section{B. Bivariate Analysis}

TABLE 6. RELATIONSHIP WITH GENESIS KNOWLEDGEPNEUMOCYSTIS

\begin{tabular}{|c|c|c|c|c|c|c|c|}
\hline \multirow[t]{2}{*}{ Knowledge } & \multicolumn{4}{|c|}{ Pneumonia } & \multirow{2}{*}{\multicolumn{2}{|c|}{ Total }} & \multirow[t]{2}{*}{ P-Value } \\
\hline & \multicolumn{2}{|c|}{ Yes } & \multicolumn{2}{|c|}{ No } & & & \\
\hline Less & 1 & $14.3 \%$ & 6 & $85.7 \%$ & 7 & $100 \%$ & \multirow{4}{*}{0,726} \\
\hline Sufficient & 3 & $23.1 \%$ & 10 & $76.9 \%$ & 13 & $100 \%$ & \\
\hline Good & 93 & $26.9 \%$ & 253 & $73.1 \%$ & 346 & $100 \%$ & \\
\hline Total & 97 & $26.5 \%$ & 269 & $73.5 \%$ & 366 & $100 \%$ & \\
\hline
\end{tabular}

Based on table 6, shows that mothers who have toddlers with pneumonia get a higher proportion of good knowledge about pneumonia that is $26.9 \%$ compared to mothers who are knowledgeable enough about pneumonia $23.1 \%$, Chi-square test results $\alpha=0.05$ obtained $\mathrm{P}=0.726$ $(\mathrm{P}>\alpha)$ this means that statistically, Ho failed to reject, which means there is no meaningful relationship between maternal knowledge about pneumonia with the incidence of pneumonia in infants.
The results showed that mothers did not know the importance of ventilation that had to be opened every day so that there was an exchange of air from outside which would enter the house, besides that it was also related to the condition of the home environment in Cilegon city which was mostly surrounded by factories so the mothers reluctant to open the windows of houses because air pollution is indeed quite high in Cilegon City.

\begin{tabular}{|c|c|c|c|c|c|c|c|}
\hline \multirow{3}{*}{$\begin{array}{c}\text { Behavior } \\
\text { Less }\end{array}$} & \multicolumn{4}{|c|}{ Pneumonia } & \multirow{2}{*}{\multicolumn{2}{|c|}{ Total }} & \multirow[t]{3}{*}{ P-Value } \\
\hline & \multicolumn{2}{|c|}{ Yes } & \multicolumn{2}{|c|}{ No } & & & \\
\hline & 10 & $40 \%$ & 15 & $60 \%$ & 25 & $100 \%$ & \\
\hline Sufficient & 43 & $25.1 \%$ & 128 & $74.9 \%$ & 171 & $100 \%$ & 0.282 \\
\hline Good & 44 & $25.9 \%$ & 126 & $74.1 \%$ & 170 & $100 \%$ & \\
\hline Total & 97 & $26.5 \%$ & 269 & $73.5 \%$ & 366 & $100 \%$ & \\
\hline
\end{tabular}

Based on table 7, it shows that mothers who have toddlers with pneumonia get a higher proportion of less behavior that is $40 \%$ compared to mothers who behave well that is $25.9 \%$, the results of the chi-test square $\alpha=0.05$ found P $=0.282(\mathrm{P}>\alpha)$ this means that statistically, Ho failed to reject, which means there is no meaningful relationship between maternal behavior with the incidence of pneumonia in infants.

The results showed that families still have the behavior to smoke in the house and there are still many who hang clothes and deviate things in their child's bedroom, this possibility also affects toddlers susceptible to coughing.

TABLE 8. RELATIONSHIP ATTITUDE MOTHER WITH PNEUMONIA

\begin{tabular}{|c|c|c|c|c|c|c|c|}
\hline \multirow{3}{*}{$\begin{array}{c}\text { Attitude } \\
\text { Less }\end{array}$} & \multicolumn{4}{|c|}{ Pneumonia } & \multirow{2}{*}{\multicolumn{2}{|c|}{ Total }} & \multirow[t]{2}{*}{ P-Value } \\
\hline & \multicolumn{2}{|c|}{ Yes } & \multicolumn{2}{|c|}{ No } & & & \\
\hline & 29 & $44.6 \%$ & 36 & $55.4 \%$ & 65 & $100 \%$ & \multirow{4}{*}{0,000} \\
\hline Sufficient & 50 & $27.6 \%$ & 131 & $72.4 \%$ & 181 & $100 \%$ & \\
\hline Good & 18 & $15 \%$ & 102 & $85 \%$ & 120 & $100 \%$ & \\
\hline Total & 97 & $26.5 \%$ & 269 & $73.5 \%$ & 366 & $100 \%$ & \\
\hline
\end{tabular}


Based on table 8, it shows that mothers who have toddlers with pneumonia have a higher proportion of less attitudes ie $44.6 \%$ compared to mothers who behave well which is $15 \%$, Chi-square test results $\alpha=0.05$ obtained $\mathrm{P}=0.000$ $(\mathrm{P}<\alpha)$ this means that statistically, Ho rejected, which means there is a significant relationship between mother's attitude to the incidence of pneumonia in Toddlers.
Results showed the data that the attitude of mothers who are lazy to clean her house every day assume that the disease pneumonia will heal itself because it is a common cough disease and the attitude of mothers who still trust their children to drink herbal medicine if the child has a cough and fever.

TABLE 9. CORRELATION EXPOSURE INFORMATION WITH PNEUMONIA

\begin{tabular}{|c|c|c|c|c|c|c|c|}
\hline \multirow[t]{2}{*}{ Exposure } & \multicolumn{4}{|c|}{ Pneumonia } & \multirow{2}{*}{\multicolumn{2}{|c|}{ Total }} & \multirow[t]{2}{*}{ P-Value } \\
\hline & \multicolumn{2}{|c|}{ Yes } & \multicolumn{2}{|c|}{ No } & & & \\
\hline Yes & 56 & $21.8 \%$ & 201 & $78.2 \%$ & 257 & $100 \%$ & \multirow{3}{*}{0002} \\
\hline No & 41 & $37.6 \%$ & 68 & $62.4 \%$ & 109 & $100 \%$ & \\
\hline Total & 97 & $26.5 \%$ & 269 & $73.5 \%$ & 366 & $100 \%$ & \\
\hline
\end{tabular}

Based on Table 9 , showed that mothers who had toddlers with pneumonia obtained a higher proportion in mothers who were exposed to information about pneumonia that was $37.6 \%$ compared to mothers who were not exposed to information about pneumonia which was $21.8 \%$, the chi-square test results $\alpha=0.05$ obtained P $=0.003(\mathrm{P}<\alpha)$ this means that statistically Ho is rejected which means there is a meaningful relationship between exposure to information about pneumonia with the incidence of pneumonia in infants.

\section{CONCLUSION}

Attitudes and information exposure have a significant relationship with the incidence of pneumonia, whereas behavior and knowledge do not have a significant relationship with the incidence of pneumonia in children under five in Cilegon city.

\section{REFERENCES}

[1] WHO, "World Pneumonia Day 2018," 2019. [Online]. Available: https://www.who.int/maternal_child_adolescent/child/worldpneumonia-day-2018/en/. [Accessed: 25-Oct-2019].

[2] Kementrian Kesehatan RI, "Data dan Informasi: Profil Kesehatan Indonesia 2017,” Jakarta, 2018.

[3] Dinas Kesehatan Kota Cilegon, "Profil Dinas Kesehatan Kota Cilegon 2018," Kota Cilegon, 2018.

[4] Howie, "Childhood pneumonia and crowding, bed-sharing and nutrition: a case- control study from The Gambia," INT $J$ TUBERC LUNG DIS, vol. 20(10), pp. 1405-15, 2016.

[5] S. Notoadmojo, Metodologi Penelitian Kesehatan. Jakarta: Rineka Cipta, 2012.

[6] R. Alfaqinisa, "Hubungan Antara Tingkat Pengetahuan, Sikap, dan Perilaku Orang Tua tentang Pneumonia dengan Tingkat Kekambuhan Pneumonia pada Balita di Wilayah Kerja Puskesmas Ngesrep Semarang," Universitas Negeri Semarang, 2015.

[7] C. C. Adesanya OA, "A multilevel analysis of lifestyle variations in symptoms of acute respiratory infection among young children under five in Nigeria," BMC Public Health, vol. 16(1), 2016.

[8] C. N. Han NTN, Pongjaturawit Y, "Factors related to self-efficacy in caring for young children with pneumonia among Vietnamese mothers," 2015.

[9] Ewnetu H, "Determinants of community acquired pneumonia among children in Kersa District, Southwest Ethiopia: Facility Based Case Control Study," J. Pediatr. Neonatal Care, vol. 5(2), pp. 1-8, 2016

[10] D. I. Anwar A, "Pneumonia pada Anak Balita di Indonesia," J. Kesehat. Masy. Nas., vol. 8(8), pp. 359-365, 2014.
[11] S. Hartati, "Analisis Faktor Risiko yang Berhubungan dengan Kejadian Pneumonia pada Anak Balita di RSUD Pasar Kebo Jakarta," 2011. [Online]. Available: lib.ui.ac.id/file?file=digital/20282632-T Susi Hartati.pdf.

[12] L. T. Ayalneh AA, Fetene DM, "Inequalities in health care utilization for common childhood illnesses in Ethiopia: evidence from the 2011 Ethiopian Demographic and Health Survey," Int. J. Equity Health, vol. 1-9, 2017.

[13] Tazinya AA, Ekane GEH, Mbuagbaw LT and O. M. Abanda M, Atashili J, "Risk factors for acute respiratory infections in children under five years attending the Bamenda Regional Hospital in Cameroon," BMC Pulm. Med., vol. 1-8, 2018. 